\title{
Framework for Technological Entrepreneurship Development: Key Issues and Policy Directions
}

\author{
Willie O. Siyanbola, Helen O. Aderemi*, Abiodun A. Egbetokun, Maruf Sanni \\ National Centre for Technology Management, Obafemi Awolowo University, Ile-Ife, Nigeria. \\ Email: ${ }^{*}$ aderemi.helen@gmail.org
}

Received August 16 $6^{\text {th }}, 2011$; revised September $17^{\text {th }}, 2011$; accepted September $24^{\text {th }}, 2011$.

\begin{abstract}
Entrepreneurship is acknowledged to be a significant driver of national wealth. In this paper, we present a framework for developing technological entrepreneurship particularly for developing countries, with supporting policy directions. Our thesis is that technological entrepreneurship, which exploits existing scientific and technological knowledge to meet market needs-is what brings about the national productivity and competitiveness that entrepreneurship is said to provide. Our framework stresses the fact that the innovation process is facilitated by technological entrepreneurship which is in turn pre-conditioned within the context of favorable policies, institutions, financial and institutional support.
\end{abstract}

Keywords: Entrepreneurship, Development, Innovation, Technological, Industrial, Commercialization, Framework

\section{Introduction}

Discussions relating to industrial development have made prominent the concept of entrepreneurship in recent times. However, it has been observed that while entrepreneurship which is the exploitation of business opportunity would bring about job creation and wealth generation, it has limitation in bringing about accelerated industrial development that would enable a country to compete in the frontiers of global rapid technological developments. Thus the concept of technological entrepreneurship has gained more and more attention among researchers, policy makers, government, scholars and firms alike. For instance, we have authors who have discussed the subject of technological entrepreneurship [1-4]. In this body of literature, emphasis seemed to be placed on high-potential technology opportunities, technical systems, innovation, production and commercialization. Within this context, very little technological entrepreneurship can be said to exist in Nigeria, and indeed in many developing economies. Most entrepreneurial activities are concentrated in non-technological priorities. This is because most technologies are foreign and im-

*This paper uses results from a 2006 policy research project of the National Centre for Technology Management (NACETEM). The project Technological Entrepreneurial Attitude in Nigerian Tertiary Institutions was funded by the Federal Government of Nigeria through the Federal Ministry of Science and Technology (FMST). For enquiries, e-mail: dg.ceo@nacetem.org or call +234(0)8033449687. ported; and continuous improvements and innovation from source countries on the imported technologies render them obsolete in no time. This paper therefore seeks to provide a framework for developing technological entrepreneurship, with supporting policy directions. To achieve this goal, the discussion focuses firstly on conceptualizing technological entrepreneurship, encapsulateing its role in social and economic development, providing data on the current status in Nigeria before concludeing with a discussion on the framework and policy directions.

\section{The Concept of Technological Entrepreneurship}

Technological entrepreneurship, also referred to as technology-based entrepreneurship, can be defined as the setting up of new enterprises by individuals or corporations to exploit technological innovation. It can also be described as the commercialization of emerging technological discoveries or innovation. Technological entrepreneurship is defined as a style of business leadership that involves identifying high-potential, technology-intensive commercial opportunities, gathering resources such as talent and capital, and managing rapid growth and significant risk using principled decision-making skills [4]. It is also defined the term as the process by which entrepreneurs assemble organizational resources 
and technical systems, and the strategies by entrepreneurrial firms to pursue opportunities [2]. Aderemi et al. [5] positioned technological entrepreneurship as being needed to make full use of the knowledge of science and technology currently available in meeting market needs, thereby making the country in question more productive and more competitive internationally [5]. This suggests the necessary involvement of a process of industrial innovation in the country's area of strength and endowment to generate productivity and competitiveness. According to them, "Technological entrepreneurship is initiated and culminated in design, development, production, engineering and commercialization of innovative new products and processes". Though the authors noted the challenge of increasing the frequency and pace of technological innovation in all sectors of the country's economy, they noted that it can lead to productivity and growth if only more and more entrepreneurs set up firms to commercialize the sectoral innovations.

\section{Features of Technological Entrepreneurship}

There are certain attributes that characterize technological entrepreneurship. These attributes are elaborated below:

\subsection{High Potential Opportunity}

A new technology-based venture is described as having a high potential opportunity if it is capable of creating new value for its customers, it has a significant level of technology understanding which is difficult to replicate and can often be protected (patented), it has a significant first mover advantage, it has a level of scalability, it creates a barrier to entry, and it also has a high level of initial risk which can be translated into high levels of return.

\subsection{Technology-Intensive Opportunity}

Technological entrepreneurship is described as a technology-intensive opportunity involving a process of problem solving, raising and safeguarding the quality of life, needing technical skills and applications, identifying potential market, improvement in quality of products in order to improve competitiveness of the firm with expectation of saving in process cost. Furthermore, the sufficient reason for embarking on technological entrepreneurship in borne out of the need to commercialize significant innovations that are expected to guarantee suppliers of materials, long-term stability of firms and increase output.

\subsection{Unique Technology Capable of Driving a New Business}

As firms can be viewed as bidding and competing for customers' purchases, and markets can be evaluated based on the extent to which the profitability of a firm hinges on meeting consumers demands if possible, better than its rivals. Consequently, aside from having more share of the market through aesthetic changes, price reduction, better performance and so on, technological entrepreneurship has the characteristic of being able to advance new technologies that can institutionalize new ventures that adequately meet consumers' need.

\subsection{High Risk of Failure}

One of the true measures of success for technological entrepreneurs is the extent to which they are able to develop and bring to market radically innovative new products. Developing new products is especially a risky business endeavor, because a technically feasible innovation might not be economically profitable, and the product may not survive the commercialization process. Literature reported that success rates for new inventions ranged from $1 \%$ to $85 \%$ [6-8]. From their observations, less than $2 \%$ of potential technology-based venture ideas (technology innovations) end up being registered as patent or intellectual property. Also less than $1 \%$ of business plans received by venture capitals get funded. In fact, many innovations that should have been commercialized into a technology-based venture end up in shelves. For instance, it was found that there is lack of faith in the Nigerian Patent Law, which in turn provided little protection for local innovations [9]. Innovators consider this a major problem in the commercialization of their products and processes; $89 \%$ had not explored the use of the patent law, even though the law had been enforced since 1970 and 6644 patents have been registered with only 177 owned by Nigerians.

\subsection{Longer Time to Market}

This refers to the uncertainty surrounding the commercial success of an innovation because it is difficult to predict the time lag between the launching of a product in the market and the growth of sales due to unforeseen circumstances that could influence the demand for the product.

\subsection{Demand of Infrastructure, Facilities and Resources}

Technological entrepreneurs are faced with several challenges to development. Literature opined that the challenge that innovative entrepreneurs face are attributable to inadequate resources, expensive patents and unavailability of equity [10]. To this list we add the non-availability of venture capital within the Nigerian environment. 


\section{The Role of Technological Entrepreneurship in Social and Economic Development}

A vast body of research exists on the importance and varied contributions of technological entrepreneurship to job creation, economic and social development, and growth. It was specifically stated and we quote as follows [11]:

Technological entrepreneurship is a key source of economic and social progress. It refers to the creation of new firms by independent entrepreneurs and corporations to exploit technological discoveries. These new firms create jobs, contribute to the well being of their communities and generate wealth for their owners. These firms are also the change makers in their respective industries as they bring in new technological paradigms that alter the dynamics of competition and rules of rivalry.

Basically, both incremental and radical innovations are important not only for the positive economic impact they typically create, but also because they fundamentally change the behavior of consumers, often in ways that improve their lives. More specifically, the following are the roles of technological entrepreneurship in socioeconomic development:

- Technological entrepreneurship is needed to propel technological innovation efforts into the market. Whenever there is a breakthrough in research and development. It is the place of technological entrepreneurship to commercialize the achievements of technological efforts otherwise, it remains in the laboratory without making any impact. One of the reasons why many research breakthroughs never leave the laboratory is due to short fall of technological entrepreneurs. And unless technological innovation or the output of research and development efforts reaches the market or are commercialized, industrialization would be elusive.

- Technological entrepreneurship has the potential of improving state of technological capability in a country. This is because as technological efforts are being made, learning takes place. This occurs either by doing or observation, thus improving technological capability in the efforts in question.

- Because technological entrepreneurship would necessarily involve the commercialization of a research output, more patents are generated and patents are a well known indicator and measure of technological development and industrialization in countries all over the world.

- Technological entrepreneurship is the platform that accelerates the diffusion of successful technological innovation in an economy. For instance in Nigeria, and in most African countries, the rate of diffusion of Information Communication Technology (ICT) is on the increase. This is made possible by the private firms that saw an opportunity and decided to market ICT products and services thereby increasing the pace of diffusion. The diffusion in turn has greatly enhanced the quality of life of the citizenries.

- For a technological entrepreneur to be relevant, he must of necessity meet market needs and be a problem solver. In a bid to meet market need, research and development as well as science and technology efforts must be well coordinated. Science and technology as well as industrialization policies are tailored towards meeting the needs of the market. This, we believe, will invariably bring about socio-economic development.

\section{Technological Entrepreneurship Development in Nigeria}

The literature on technological entrepreneurship is sparse in Nigeria and technological entrepreneurs are very few. For instance, in a study of technological and non-technological women entrepreneurs in South-Western Nigeria, the women in non-technological businesses were about twice as many as those in technological businesses [5]. Entrepreneurs are catalysts of change in a market economy. They spur efficient use of resources and facilitate transactions between parties with different preferences and endowments [12]. Central to entrepreneurial behaviour is the acceleration, generation, dissemination and application of innovative ideas. In the developing countries such as Nigeria, high level of entrepreneurship is important in reducing the adverse socioeconomic impacts by creating new employments. A society with a strong entrepreneurial culture have a positive influence on the rate at which new firms are created and their chances of survival and growth as well as the fate of already existing firms [12]. In a more specific sense, entrepreneurship is the vehicle on which innovation, which is the application of knowledge in production, rides. Indeed, innovation is at the heart of entrepreneurship. Within this context, entrepreneurs are considered as "champions" of some sort who convert ideas into products and services and ultimately create wealth and reduce unemployment [13]. In this section, we consider some critical issues and current research regarding technological entrepreneurship in Nigeria.

\subsection{Current Status of Technological Entrepreneurial Interest among Students and Women}

Technology-based entrepreneurship, or simply technological entrepreneurship, in particular, is a strong driving 
force for socio-economic growth in the global economy. Technological entrepreneurship is a vital ingredient in any effective National or Regional Innovation System. A recent research on the status of Technological Entrepreneurial Attitude in Nigerian Tertiary Institutions revealed that majority of undergraduates in Nigeria indicated a preference for technological entrepreneurship but much fewer of them has actually practiced entrepreneurship (see Table 1). The major constraints identified are poor funding, inadequate preparation through training and institutional weaknesses expressed in the inadequacy of government support to young and aspiring entrepreneurs [14]. More detailed analysis revealed that $1.4 \%$ of them showed interest in both technological and non-technological entrepreneurship (Figure 1). While there might be those with unclear preferences, these results imply that most of the students have a preference for entrepreneurship and for technology-based businesses but the expression of these interests in practice is rather low. Ensuring, first and foremost, that this high level of interest is sustained and that it is actually expressed in business start-ups, should be the target of any entrepreneurship-related policy intervention.

Furthermore, we note that studies on women technological entrepreneurship in Nigeria is concentrated on the informal sector. For instance, informal economic activeties by women in Nigeria encompass a wide range of small-scale, largely self-employment businesses [5]. The study reported that $37 \%$ of the respondents were engaged in technology-based ventures including food, beverage and tobacco production, water processing and packaging, mining and quarrying (excluding petroleum), building and construction, wood-work and furniture making, garment making, metal fabrication and iron works, among others. On the other hand, $63 \%$ of the respondents had non-technological businesses including education services, health services, counseling services, retail trade, transport, restaurant, financial outfits, among others. This suggests a higher prevalence of non-technology-based entrepreneurship among women, and indicates the need for interventions directed at the development of technology-based entrepreneurship in the country.

\subsection{Entrepreneurial Motivation and Challenges}

Among students, common influence on entrepreneurship in Western countries is family background, where family origin in general was found to offer positive role models [15]. A stylized fact emerging from research shows individuals whose parents were either self employed or business owners to be more likely to become entrepreneurs than those from families without such entrepreneurial experience $[16,17]$. Such a family background is said to transport knowledge, skills, self-confidence and also
Table 1. Entrepreneurial preference of Nigerian undergraduates*.

\begin{tabular}{lc}
\hline \multicolumn{1}{c}{ Entrepreneurial Disposition } & Percentage \\
\hline Interested in starting own business & 83.6 \\
Interested in starting a technology-based business & 69.9 \\
Presently engaged in a business & 26.9 \\
\hline
\end{tabular}

*The proportions are based on 5898 student respondents.

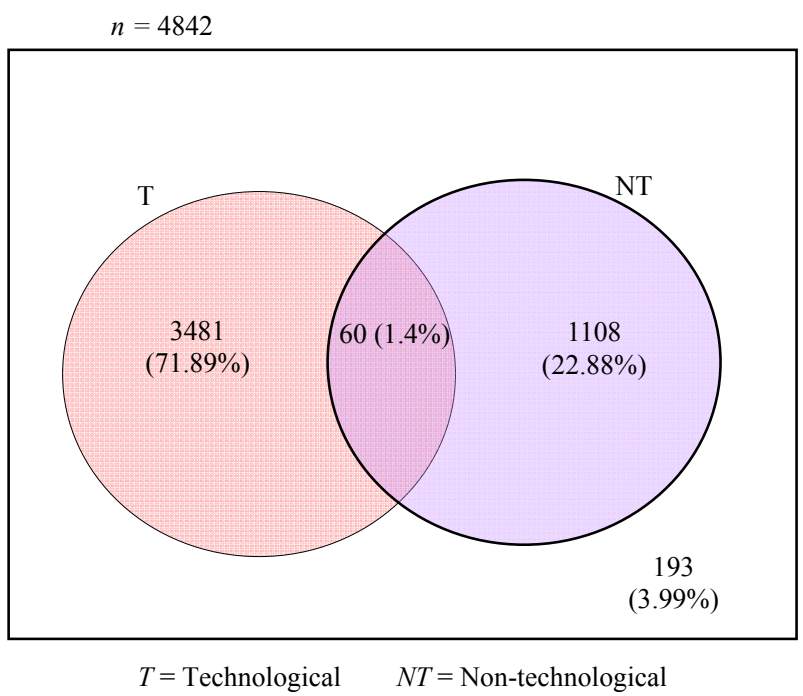

Figure 1. Specific classification of students' preferred business type.

positive attitudes towards entrepreneurship, thus facilitating entry of their children into entrepreneurship. Interestingly, findings from the study on undergraduates' entrepreneurial propensity in Nigeria revealed that most students who are already involved in entrepreneurship were motivated by personal interest and parental influence (Table 2).

About 1 in every 3 students who reported that they were already involved in business cited their personal interest as the most important motivating factor [14]. The influence of parents and desire to make money, which could be due to survival pressure, genuine needs or sheer curiosity, are the next most important motivating factors. Obviously, entrepreneurial interest among Nigerian students is already high. Thus, government policies on entrepreneurship should also pay attention to other factors that could promote entrepreneurial behavior among the youths. These factors include the presence of highly influential mentors and finding means of encouraging personal savings.

Among women, sources of information, educational background, the presence of a role model/mentor, sociocultural factors, age and prior training correlated signify- 
cantly with the choice of enterprise by women entrepreneurs in south-western Nigeria (Table 3) [5]. These results present issues on education, information and enabling environment that has to be addressed in the development of technological entrepreneurship.

\subsection{The Role of Education}

In nurturing potential entrepreneurs, education plays a vital role. Entrepreneurial education has been recognised as one of the crucial factors that help the youth to understand and cultivate entrepreneurial attitudes [18,19]. While there might be some people with inherent entrepreneurial drive and inclinations from other non-technical sources, the tertiary education system presents one of the best and most viable sources to recruit new technological entrepreneurs. Thus, there is a need to understand how to develop entrepreneurial skills among students while still in school. Their knowledge of and attitude towards entrepreneurship do influence their inclination to start their own business in the future.

In Nigeria, government's approach to solving the problem of unemployment has historically been unmindful of the potential role of entrepreneurial education despite many attempts to formulate useful policies and/or programmes to support employment generation in the country. The high unemployment rate in Nigeria which was put at about $37 \%$ as at 2004 may well be a conesquence of the foregoing [20]. For example, statistics show that during the 1994-1997 periods, there were about 260,000 finalists in the nation's tertiary institutions, with a total of 100,000 registered unemployed persons already in the labor market. During the same period, only a total of about 20,000 registered senior level and professional vacancies existed in the labor market to take care of the potentially unemployed graduates. By 2000-2003, the total number of finalists in tertiary institutions was about 420,000 ; by which time total registered unemployment

Table 2. Motivating factors for students' involvement in business.

\begin{tabular}{cc}
\hline Factors & Percent $(\mathrm{n}=1861)$ \\
\hline Personal interest & 30.74 \\
Parent & 19.29 \\
Desire to make money & 17.25 \\
Self-actualization & 15.91 \\
Peers & 5.64 \\
Relatives & 4.67 \\
Sibling & 3.44 \\
Events & 3.06 \\
\hline
\end{tabular}

Table 3. Factors responsible for the choice of enterprise by women entrepreneurs in south-western Nigeria.

\begin{tabular}{lcc}
\hline \multicolumn{1}{c}{ Variable } & $\begin{array}{c}\text { Chi-Square } \\
\text { Value }\end{array}$ & $\begin{array}{c}\text { Pearson, Phi \& } \\
\text { Cramer's V Value }\end{array}$ \\
\hline Business motivation & 8.52 & 0.23 \\
Information Sources & & \\
Television & $7.33^{*}$ & $-0.22^{*}$ \\
Trade fair & $4.37^{*}$ & $0.17^{*}$ \\
Community outreach programme & $5.46^{*}$ & $-0.19^{*}$ \\
Other Variables & & \\
Educational background & $22.08^{*}$ & $0.38^{*}$ \\
Level of education & 8.32 & 0.23 \\
Role Model/Mentor & $5.17^{*}$ & $-0.18^{*}$ \\
Social-cultural factor & $4.34^{*}$ & $-0.17^{*}$ \\
Financial support & 1.33 & -0.09 \\
Pre-venture economic situation & 4.16 & 0.16 \\
Marital status & 3.84 & 0.16 \\
Age of children & 4.26 & 0.17 \\
Children occupation & 2.76 & 0.15 \\
Nature of business & 5.72 & 0.19 \\
Parent's occupation & 0.07 & -0.02 \\
Respondent' age & $5.79^{*}$ & $0.62^{*}$ \\
Prior training in venture & $4.24^{*}$ & $0.17^{*}$ \\
Starting capital & 1.15 & -0.09 \\
Getting the business registered & 0.68 & -0.07 \\
\hline
\end{tabular}

*Significant at the $95 \%$ level.

had increased to about 150,000 . However, total Registered senior level and professional vacancies marginally increased to approximately 24,000 [21]. From the foregoing, it is indicated that between 1994 and 2003, the labor market grew by about $58 \%$ while employment opportunities increased by only $20 \%$ between the same period. The existence of such a huge gap could be an indication that propensity for entrepreneurship is rather low.

There is empirical evidence supporting entrepreneurial education as an intervention tool for impacting adult attitudes towards entrepreneurship. For instance, entrepreneurship education has been found to be an important component of economic strategies for fostering job creation [22]. More specifically, effective youth entrepreneurship education prepares young people to be respon- 
sible, enterprising individuals who become entrepreneurs or entrepreneurial thinkers and contribute to economic development and sustainable communities [23]. In addition, entrepreneurship education programmes assist individuals create value through the recognition of business opportunity, exercise of communication and management skills and development of personal competencies necessary to mobilize the resources that will bring the opportunity into reality. It is therefore not surprising that a recent study found a significant relationship $(\mathrm{r}=0.163$; $\mathrm{p}<$ 0.01 ) between students' exposure to entrepreneurial education and their interest in starting their own business [12]; where $r$ is the Pearson product moment correlation coefficient and $\mathrm{p}$ is the statistical significance level of the result at $99 \%$ confidence level.

\section{Framework for Technological Entrepreneurship Development}

Entrepreneurship development has been said to focus on individuals who wishes to start or expand a business while small and medium enterprise (SME) development, on the other hand, focuses on developing the enterprise irrespective of whether the individual in charge can be considered entrepreneurial or not [24]. Furthermore, entrepreneurship development concentrates more on growth potential and innovation than SME development does. However, many of the lessons learned from experiences in both types of development are similar. The framework presented in this paper (Figure 2) is based on the premise that innovation and entrepreneurship cannot be separated in discussions about technological entrepreneurship. This is because of our adopted definition that technological entrepreneurship is the creation of new ventures to exploit technological innovations and discoveries.

Thus, the innovation process has been introduced into the framework with technological entrepreneurship as the culminating event, and policies as well as other moderating and fiscal factors like institutions, infrastructure, education and finance serving as the enabling environment to bring about the desired visible industrialisation and development. A study reported that some food companies that followed all the seven phases of the innovation process (idea generation, screening of ideas, R \& D, business analysis, prototype development, test marketing and commercialization) in an integrative and overlapping manner in the development of new products succeeded in their commercialization efforts in Nigeria [25].

Essentially, the framework (Figure 2) suggests that technological entrepreneurship facilitates the innovation process by creating the impetus that drives each step in

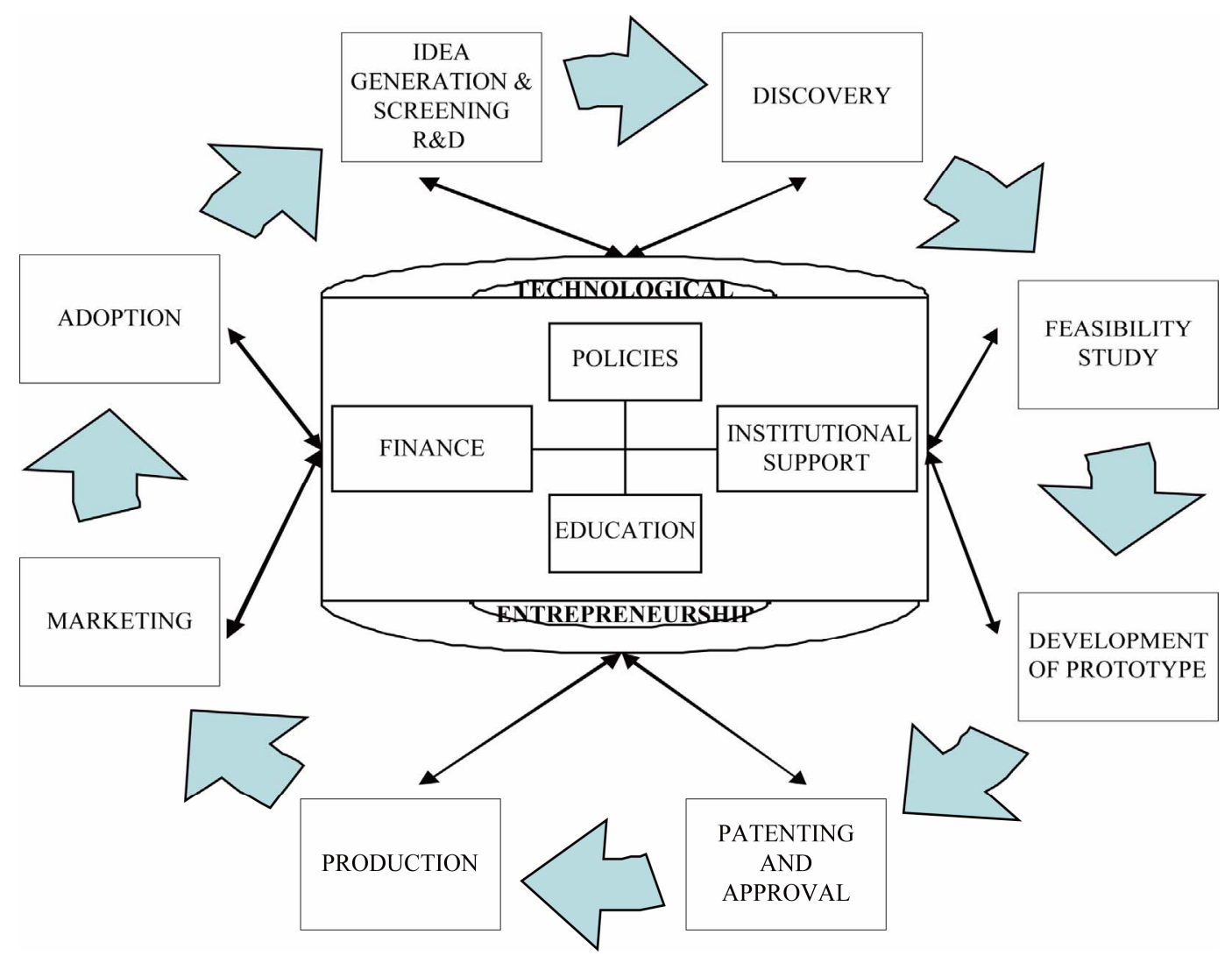

Figure 2. Framework for technological entrepreneurship development. 
the process, and dictating the mode and quality of value creation from those steps. In turn, technological entrepreneurship is facilitated within the context of favorable policies, institutions, financial and institutional support. A discussion of the specific steps of the innovation process through which the technological entrepreneurship makes its impact follows.

\subsection{Generation and Screening of Ideas}

Programmes of technological development can be driven by new product concepts and ideas. A business idea is the response of individual(s) to solving an identified problem or meeting perceived needs in the environment (markets, community, nation etc.). Ideas are needed to start a new business and/or improve an old one; to respond to market needs; to respond to changing fashions and requirements; to stay ahead of competition; to address the challenge of product life cycle; to exploit technology among others. However, ideas alone are not sufficient; they must become opportunities for entrepreneurship to occur. Opportunities are created when an attractive idea provides the possibility of good returns for the investor or individual taking the risk. In other words, a genuine business opportunity for a proposed product refers to a need for the proposed product in sufficient volume at high enough price and low enough cost to enable the entrepreneur to operate at a profit. A good business idea is not necessarily a good business opportunity until it has passed the profitability and feasibility tests.

\subsubsection{Typical Sources of Business Ideas}

There are various sources of business ideas or opportunities:

1) Observation and being sensitive to one's environment by making use of the five senses viz:

- Sight-seeing not just looking

- Hearing-listening to what people are saying

- Smell-smelling and asking questions

- Taste-tasting and asking questions

- Touch-touching and asking questions

The ability to observe the environment is not common. Most people look without seeing. A technological entrepreneur possesses observation skill to a high extent. He sees opportunity in poor delivery of a product, overpriced product, and advances in technology, failure of a product or company, a monopoly, adaptation or imitation and in a rapidly expanding market.

2) Internal sources which include suggestions from peers or family, personal hobbies and interests, creativity, personal skills and experience. It has been noted that Professional engineers due to their education, training, and work experience are well positioned to practice technological entrepreneurship [5].
3) External sources which include friends, one's bankers, customers, suppliers, franchises, mass media, published market statistics, exhibition/market surveys, brainstorming, research institutes, trade association, universities, government agencies among others.

\subsubsection{The Process of Generating, Screening and Selection of Venture Ideas}

Identification and assessment of business opportunity is referred to as the "discovery" in the framework. In existing firms, ideas usually originate from the R \& D Organization/department, and from specific market needs. These two sources of new technology ideas have in recent years been described as technology push and market pull respectively. Identifying and assessing business opportunities involves in essence, determining risks and returns reflecting factors such as industry and market, length of the window of opportunity, personal goals and competences of the technological entrepreneur, management team, capital, technology and other resource requirements, competition, environment and finally Feasibility report.

\subsection{Feasibility Study}

Feasibility study is a requirement in the development of a technology-based enterprise. It is a well researched area having practical denotation. It is usually prepared for business start-ups, expansion, modernization, restructureing and diversification. An author described it as a sine qua non for the establishment of any industrial venture and posed that one of the major challenges that investors have in promoting venture ideas is poorly packaged feasibility report because of unreliable information and faulty assumptions on which the projections are premised [26].

A feasibility study is an examination of the technical, economic and commercial viability of a proposed project. It is a multidisciplinary assignment that only consultants or technical and experienced specialists with the requisite education and training can undertake. In feasibility study, a thorough analysis and interpretation of all the basic issues relating to the project, its environment and all available alternatives are examined [27]. This step is very important for the development of technological entrepreneurship and should be taken seriously.

Once the opportunity has been discovered, feasibility study has the following roles to play in the development of the technological venture:

1) It helps in the identification and selection of resources and in avoiding investment overrun;

2) It helps in making of investment decisions;

3) It guides the entrepreneur in the allocation of resources;

4) It provides a work plan for implementation; 
5) It helps in keeping the business focused and in the determination of growth pattern;

6) It helps in securing licenses and government approval for the product or venture;

7) It is used for post audit review;

8) It helps in getting collaborators and sponsors for the venture.

Some of the activities undertaken under feasibility study include fact finding, research or research, analysis and interpretation of data among others. At the end of the feasibility study, a report would be generated that would include the following: executive summary, introduction, market and marketing, project engineering, materials, production and plants, location and site, project implementation, financial and economic evaluation and conclusion.

\subsection{Development of Prototypes}

This phase is particularly critical for innovation driven by technology-based entrepreneurship to occur. In most cases, the knowledge required at this stage comes from formal R \& D. In this stage, the idea on paper is translated into a physical product or process, and its production feasibility is assessed. During this phase, standards and requirements are met to ensure that the product is sufficiently competitive.

\subsection{Patenting and Approval}

Patenting is a critical but optional ${ }^{1}$ aspect of technology innovation entrepreneurship development. It is the right granted an inventor by the state (government), which allows the inventor to exclude anyone else from commercially exploiting his invention for a limited period, usually 20 years. This period would allow the inventor (innovator) to have made maximum returns on his investment and idea. There are four basic ways the patentee (the owner of the patent, or the patent owner) may exploit the patent. These are by commercialization through:

1) Start-ups: further development of invention or innovation in incubators at science and technology parks, etc.

2) Spin-outs (or spin-offs): These are direct exploitations through the formation of business entities (or technological enterprises) to commercialize the invention or innovation.

3) Assignment/sale of patent: the patentee may sell or assign his rights to the invention to someone else or an organisation, who will then become the new owner of the patent.

4) Licensing: a license is an authorization given by a

${ }^{1}$ Patenting is required to maximize the returns from a technology that is novel. As this is not always the case, the patenting step does not always have to occur. patentee or a government authority to other parties to use the invention. These could be either through voluntary or compulsory license.

- Voluntary license: this is an authorization given by a patentee to other parties to use the invention based on mutually-agreed terms.

- Compulsory license.

\subsection{Production and Marketing}

When all necessary approvals have been obtained, fullscale production and marketing programmes are perfected and the product is launched into the market.

\subsection{Adoption}

After launching into the market, the product enters its life cycle, and the external competitive environment becomes a major determinant of its survival.

\section{Policy Requirements for Technological Entrepreneurship Development in Nigeria}

Many policies covering different sectors of the Nigerian economy have been put in place to guide the development of entrepreneurship in Nigeria; but without a concise and effective Science \& Technology (S \& T) policy, the industrial and other related policies will only promote commerce [8]. As noted, the Nigerian S \& T policy, together with most other related ones is defective in either formation or implementation [25]. For instance, the National Economic Empowerment and Development Strategy (NEEDS) emphasized the development of an Industrial sector that will be internationally competitive but in the NEEDS document, there was no mention of the role of $S \& T$. The realization of this deficiency led to the development of NEEDS-II which was still in its infancy when the government of the day handed over to the present one. Today, despite the extent of advocacy and intellectual support in favor of the role of $\mathrm{S} \& \mathrm{~T}$ in realising the administration's 7-point Agenda, Vision 20-2020 and the current transformation agenda, government commitment to $\mathrm{S} \& \mathrm{~T}$ is still demonstrably low ${ }^{2}$.

It is important to note also, that entrepreneurial interest among Nigerian students is quite high but the expression of this interest in practice is rather low. The main factors found to be responsible for this are poor funding and inadequate preparation through training. A particularly key institutional weaknesses identified was expressed in the inadequacy of government support to young and aspiring entrepreneurs. In fact, until recently when the NUC directed all universities in the country to establish entrepreneurship centers, youth entrepreneurship has been left in the domain of agencies and non-govern-

${ }^{2}$ For instance, government funding of $\mathrm{S} \& \mathrm{~T}$ is still below the UNE SCO-recommended $1 \%$ of GDP. 
mental organizations.

Much has been said about entrepreneurial education and its importance in stimulating and sustaining entrepreneurship, especially among students. In implementing this, however, it is important to note that a uniform curriculum might not yield optimal results across different disciplines or levels. The design of these curricula should, therefore, consider the peculiarities of each discipline when issues and resource persons are being selected. As a necessity, entrepreneurial training initiatives should include a standardized monitoring and evaluation structure which ensures strict conformance with quality.

Besides the strictly formal training, entrepreneurial advocacy is also very beneficial. Institutions, of their own volition should seek to organize seminars, workshops, symposia and other similar forums where students could be brought in contact with state-of-the-art knowledge in the practice of entrepreneurship. These forums also hold the benefit of motivating the students by bringing them in contact with excelling nascent entrepreneurs.

In implementing all of the foregoing recommendations, the place of a stable political atmosphere, strong institutions and sustainable funding cannot be over-emphasized. Few, if any, policies and programmes would ever work in situations of chaos and scarcity of resources. It then rests on the government of the day to work assiduously at creating a crime-free and peaceful environment without which entrepreneurship, which is the vehicle of innovation, cannot succeed.

\section{Acknowledgements}

The authors gratefully acknowledge the support and contributions of the other members of NACETEM's entrepreneurship research team that originally implemented the project Technological Entrepreneurial Attitude in Nigerian Tertiary Institutions: Mr. O. O. Afolabi (Project Secretary), Mr. A. D. Dada and Dr. O. A. Jesuleye of NACETEM as well as Prof. M. O. Ilori of the former Technology Planning and Development Unit now African Institute for Science Policy and Innovation, and Dr. S. A. Adegbite of the Centre for Industrial Research both in Obafemi Awolowo University, Ile-Ife. The funding from the Federal Government through the Federal Ministry of Science and Technology with Prof. Turner T. Isoun as the Honourable Minister of Science and Technology at that time is gratefully acknowledged. The scrutiny and contributions of anonymous reviewers is also appreciated.

\section{REFERENCES}

[1] D. C. Mowery and S. Shane, "Introduction to the Special Issue on University Entrepreneurship and Technology Transfer," Management Science, Vol. 48, No. 1, January
2002, pp. 5-9. doi:10.1287/mnsc.48.1.0.14277

[2] S. Shane and S. Venkataraman, "Guest Editors' Introduction to the Special Issue: Technology Entrepreneurship," Research Policy, Vol. 32, No. 2, 2003, pp. 181-184. doi:10.1016/S0048-7333(02)00104-X

[3] P. Phan, and M. Foo, "Technological Entrepreneurship in Emerging Regions," Journal of Business Venturing, Vol.19, No. 1, 2004, pp. 1-5. doi:10.1016/S0883-9026(02)00116-7

[4] R. C. Dorf and T. H. Byers, "Technology Ventures: From Idea to Enterprise," 2nd Edition, McGraw Hill, New York, 2007.

[5] H. O. Aderemi, M. O. Ilori, W. O. Siyanbola, S. A. Adegbite and I. O. Abereijo, "An Assessment of the Choice and Performance of Women Entrepreneurs in Technological and Non-Technological Enterprises in Southwestern Nigeria," African Journal of Business Management, Vol. 2, No. 10, October 2008, pp. 165-176.

[6] C. Cooper, "Science, Technology and Development: The Political Economy of Technical Advance in Under-developed Countries," Frank Cass \& Co., Ltd., London, 1978.

[7] C. M. Crawford, "New Product Failure Rate: Facts and Fallacies," Research Management, Vol. 22, No. 5, 1997, pp. 9-13.

[8] M. O. Ilori, "From Science to Technology and Innovation," Inaugural Lecture Series, Vol. 191, Obafemi Awolowo University, Ile-Ife, 2006, p. 37.

[9] Adjebeng-Asem, "Translating Technical Innovation into Entrepreneurship in Nigeria: Social and Policy Implications," International Development and Research Centre (IDRC), 1995.

[10] P. Z. Nwafor, "Practical Approach to Entrepreneurship: Small and Medium Scale Enterprises (SMEs)," 2007.

[11] S. A. Zahra and J. C. Hayton, "Technological Entrepreneurship: Key Themes and Emerging Research Directions," Crossroads of Entrepreneurship, Springer, 2007, pp. 185-208.

[12] S. Arzeni, "Entrepreneurship," The OECD Observer, No. 209, 1998.

[13] M. N. Othman, Ghazali, Ezlika and S. S. Yeoh, "Graduate versus Non-Graduate Entrepreneurs in Urban Malaysia: Some Insights into Entrepreneurial Personality, Company and Family Background Differences," Journal of International Business and Entrepreneurship Development, Vol. 3, No. 1-2, 2006, pp. 57-76. doi:10.1504/JIBED.2006.011951

[14] National Centre for Technology Management (NACETEM), "Technological Entrepreneurial Attitude in Nigerian Tertiary Institutions," Policy Research Project, No. 2519/S.1/C.3/05/2637, funded by the Federal Government of Nigeria, 2008.

[15] A. Shapero and L. Sokol, "The Social Dimensions of Entrepreneurship," In: C. A. Kent, D. L. Sexton, et al., eds., Encyclopedia of Entrepreneurship, Prentice Hall, Englewood Cliffs, 1982, pp. 72-90. 
[16] T. Dunn and D. Holtz-Eakin, "Financial Capital, Human Capital, and the Transition to Self-Employment: Evidence from Intergenerational Links," Journal of Labor Economics, Vol. 18, No. 2, 2000, pp. 282-305. doi:10.1086/209959

[17] A. Laferrere, "Self-Employment and Intergenerational Transfers," International Journal of Sociology, Vol. 31, No. 1, 2001, pp. 3-26.

[18] G. Gorman, D. Hanlon and W. King, "Some Research Perspectives on Entrepreneurial Education, Enterprise Education and Education for Small Business Management: A Ten Year Review," International Small Business Journal, Vol. 15, No. 3, 1997, pp. 56-77. doi: $10.1177 / 0266242697153004$

[19] M. L. Kourilsky and W. B. Walstad, "Entrepreneurship and Female Youth: Knowledge, Attitudes, Gender Differences and Educational Practices," Journal of Business Venturing, Vol. 13, No. 1, 1998, pp. 77-78. doi:10.1016/S0883-9026(97)00032-3

[20] National Planning Commission (NPC), "Meeting Everyone's Needs: National Economic Empowerment and Development Strategy," Nigerian National Planning Commission, Abuja, 2004.

[21] J. O. Ajetomobi and A. B. Ayanwale, "Education Allocation, Unemployment and Economy Growth in Nigeria:
1970-2004," Paper Prepared for the Regional Conference on "Education in West Africa: Constraints and Opportunities," Dakar, 1-2 November 2005.

[22] W. E. McMullan, W. A. Long and J. B. Graham, "Entrepreneurship Education in the Nineties," Journal of Business Venturing, Vol. 2, No. 3, 1986, pp. 261-275. doi:10.1016/0883-9026(87)90013-9

[23] Consortium for Entrepreneurship Education, "National content Standards for Entrepreneurship Education," Retrieved June 2009.

[24] United Nations Development Programme, "Essential of Entrepreneurship: Synthesis of Lessons Learned," UNDP Evaluation Office, 1999.

[25] S. A. Sanni, M. O. Ilori and J. S. Oke, "Management of New Product Development in Selected Food Companies in Nigeria," Technovation: The International Journal of Technological Innovation, Entrepreneurship and Technology Management, Vol. 20, 2002, pp. 333-342.

[26] S. A. Adegbite, "Preparation of Industrial Feasibility Study: A Case Study Approach," Obafemi Awolowo University Press Ltd., Ile-Ife, 2005.

[27] I. O. W. Awe, "Feasibility Report Writing: A Practical Approach: In Entrepreneurship Development in Nigeria," University of Ado-Ekiti Press, Ado-Ekiti, 2006. 